\title{
A cross-sectional study of exposures, lung function and respiratory symptoms among aluminium cast-house workers
}

\author{
F G B G J van Rooy, ${ }^{1,2,3}$ R Houba, ${ }^{1}$ H Stigter, ${ }^{1}$ V A C Zaat, ${ }^{1}$ M M Zengeni, ${ }^{1,2}$ \\ J M Rooyackers, ${ }^{1,4}$ H E Boers, ${ }^{5}$ D J J Heederik ${ }^{2,6}$
}

${ }^{1}$ Netherlands Expertise Centre for Occupational Respiratory Disorders, Utrecht, The Netherlands

${ }^{2}$ Division of Environmental Epidemiology, Institute for Risk Assessment Sciences, Utrecht University, The Netherlands

${ }^{3}$ Arbo Unie Expert Centre for Chemical Risk Management, Utrecht, The Netherlands ${ }^{4}$ Department of Respiratory Medicine, Division of Heart and Lungs, University Medical Centre Utrecht, Utrecht, The Netherlands

${ }^{5}$ Arbo-adviesburo Akkoord, Beerta, The Netherlands ${ }^{6}$ Julius Centre for Health Sciences and Primary Care, University Medical Centre Utrecht, Utrecht, The Netherlands

\section{Correspondence to}

Dr F G B G J van Rooy, Division of Environmental Epidemiology, Institute for Risk Assessment Sciences, PO Box 80.178, Utrecht NL-3508 TD, The Netherlands; f.vanrooy@uu.nl

Accepted 22 March 2011 Published Online First 14 April 2011

\section{ABSTRACT}

Objectives To investigate exposures, respiratory symptoms, lung function and exposure-response relationships among aluminium cast-house workers. Methods A cross-sectional study was conducted among 182 workers. Exposure data were used to model exposure to irritants. Lung function and questionnaire data on respiratory symptoms were compared to a general population sample and an internal reference group. Blood samples were taken from 156 workers to examine total $\lg \mathrm{E}$, eosinophils and sensitisation to common allergens.

Results Average daily mean exposure to inhalable dust, metals, hydrogen fluoride, fluoride salts and sulphur dioxide was relatively low compared to reference values. Airflow patterns in the hall were disturbed regularly and resulted in pot emissions with high concentrations of fluorides. Peak exposures to chlorine gas occurred intermittently due to production process disturbances. Workers reported significantly more respiratory symptoms (continuous trouble with breathing (prevalence ratio (PR) 2.5; $95 \% \mathrm{Cl} 1.2$ to 5.3), repeated trouble with breathing (PR 1.8; 95\% Cl 1.1 to 3.0), wheezing (PR 1.4; 95\% Cl 1.1 to 1.8 ), asthma attack (ever) (PR 2.8; $95 \% \mathrm{Cl} 1.7$ to 4.6 ) and doctor diagnosed asthma (PR 2.6; $95 \% \mathrm{Cl} 1.5$ to 4.4). Regression analysis showed significantly lower $\mathrm{FEV}_{1}$ values $(-195 \mathrm{ml})$ and FVC values $(-142 \mathrm{ml})$ compared to a general population sample. Lung function did not differ between groups.

Conclusion This epidemiological study suggests cast-house workers in the aluminium industry are exposed to respiratory hazards. Exposure-response relationships could not be demonstrated but this study supports preventive measures in the work environment with a focus on (peak) exposures to irritants.

\section{INTRODUCTION}

Respiratory health effects and diseases are well known in the aluminium industry ${ }^{1-5}$ and exposure to irritants in the aluminium industry is associated with respiratory symptoms and asthma. ${ }^{6-10}$ Associations between respiratory symptoms and particulate and gaseous fluorides have been reported in potroom workers ${ }^{11}$ and between respiratory symptoms and total fluorides and inhalable dusts in aluminium smelters. ${ }^{12}$ Bronchial responsiveness in aluminium potroom workers reporting workrelated asthmatic symptoms was reported to be related to fluoride plasma levels, but the mechanism has still to be clarified. ${ }^{2}$

\section{What this paper adds}

- Respiratory diseases and adverse respiratory health effects are common among workers in the aluminium industry.

- Working as an aluminium cast-house worker has not previously been associated with adverse respiratory health effects.

- This study provides important new data about peak exposures to irritants including fluorines and chlorine.

- This epidemiological study examines the respiratory hazards experienced by aluminium casthouse workers.

- This study supports preventive measures in the work environment with a focus on (peak) exposures to irritants.

Respiratory symptoms among aluminium smelter workers are reported by potroom workers as well as ingot mill and anode workers. ${ }^{13}$ However, until now, working as an aluminium cast-house worker has not been associated with adverse respiratory health effects. ${ }^{14-16}$

Field found that the prevalence of asthma-like symptoms in potroom workers in the aluminium industry ranged from $20 \%$ to $57 \%$ and that there was a similar range in aluminium casting workers. ${ }^{14}$ In a study of 30 workers from an aluminium casting plant, Godderis et al found among no significant difference in any of the respiratory questionnaire categories or in the results of spirometry tests between cast-house personnel and referents. ${ }^{15}$

Despite modernisation of an aluminium production factory in Bosnia and Herzegovina aimed at reducing the amount of harmful substances at work, high concentrations of chlorine in the cast-house remained the biggest problem. ${ }^{16}$

We carried out a study among aluminium cast-house workers with long-standing respiratory symptoms because the hygienic measures taken so far did not lead to a decrease respiratory complaints.

The aim of our study was to assess (peak) exposures, the prevalence of respiratory symptoms and lung function among aluminium cast-house workers in an aluminium producing plant in the Netherlands. 


\section{METHODS}

\section{Study design, participants and setting}

We identified 182 eligible aluminium cast-house workers who were potentially exposed to airway irritants in an aluminium producing plant in the Netherlands. We obtained written, informed consent from 157 (86\%) workers; only a few of the remaining 25 (14\%) workers gave their reasons for not participating (eg, having a chronic illness or leaving the plant for another job). In the summer of 2008 we conducted a crosssectional study among the 157 consenting workers: 151 (96\%) completed the questionnaire, 155 (99\%) underwent spirometric lung function tests and 156 (99\%) gave blood samples.

We used data from the Dutch contribution to the European Community Respiratory Health Survey (ECRHS), ${ }^{17}$ a general population sample, to compare symptom prevalence between the two groups. We used data from males aged between 30 and 65 ( $n=144$ aluminium cast-house workers and $n=1000$ subjects from the ECRHS population). For analysis of lung function data, we only used data from Caucasian males aged 30-65 ( $\mathrm{n}=138$ aluminium cast-house workers and $\mathrm{n}=972$ subjects from the ECRHS population) as there were too few female or non-Caucasian workers in the population of aluminium cast-house workers.

\section{Production process}

Aluminium production consists of at least two operations. The first is electrolytic production of aluminium with prebaked anodes using the Hall-Héroult process. Alumina (aluminium oxide) arrives at the plant and is fed into furnaces filled with liquid electrolyte (containing cryolite). The alumina is dissolved at $960^{\circ} \mathrm{C}$ and an electric charge of $140000 \mathrm{~A}$ is passed through the solution. The alumina splits off and the aluminium sinks to the bottom of the furnace, is removed and is transported to the foundry/cast house in transport ladles. The second operation is aluminium casting. Aluminium is degassed with chlorine before casting and is mixed with other materials to obtain the correct quality and properties to meet customers' requirements. The aluminium is then cast in the form of rolling ingots or extrusion billets in vertical casting machines. The plant produces 160000 tonnes of aluminium annually (110000 tons of new aluminium and another 50000 tonnes through remelting and recycling).

\section{Exposure assessment}

Personal full-shift inhalable dust samples were collected in the workers' breathing zones using PAS- 6 sampling heads and mixed cellulose ester filters at a flow rate of $21 / \mathrm{min}$. One personal sample and two area sedimentation samples were analysed for several metals using inductively coupled plasma analysis.

Workers' exposure to fluorides was assessed by short-term (18-55 min) and full-shift (6-8 h) personal and area sampling of gaseous and particulate fluorides, using MDHS 35/2. ${ }^{18}$ Particulate and gaseous fluorides were captured and analysed separately using disposable three-piece plastic filter cassettes. In addition, over two working days, all eligible cast-house workers and 13 controls were asked to provide a urine sample before and after each shift in a collection cup pre-treated with $0.2 \mathrm{~g}$ EDTA. A total of 55 samples were collected and analysed according to NIOSH Method 8308 with results expressed as milligrams fluoride per gram of creatinine. ${ }^{19}$ To explore exposure emissions within the cast-house area, real-time hydrogen fluoride (HF) concentrations were measured with tunable diode laser (TDL) technology, using a commercially available TDL-based instrument (GasFinder; Boreal Laser, Spruce Grove, Alberta, Canada). Sulphur dioxide and chlorine were measured during walk-through sessions on several days using a commercially available real-time instrument with substance-specific toxic sensors $\left(\mathrm{ORAE}^{+}\right.$; RAE Systems BeNeLux BV, Capelle a/d IJssel, The Netherlands).

Based on current job title, relative distance to emission sources of respiratory irritants and expected duration of the presence of each job title in the cast-house area during the day, all workers were divided into three exposure groups with increasing (expected) exposure to respiratory irritants. The exposure groups were defined based on a semi-quantitative exposure assessment. When creating the groups, we used the specified task description of all jobs in the cast-house area in combination with the available exposure measurements. Unfortunately, we were not able to define the groups based on exposure measurements only as personal exposure levels could not be exactly quantified for several agents. Instead, we had to use surrogates of exposure, for example the distance between the activity and known sources of $\mathrm{HF}$ emissions, and if taking samples (with short-term chlorine exposure) was part of the regular activity.

\section{Questionnaire}

Participants completed a self-administered standardised questionnaire supplemented with questions about respiratory, mucous membrane ${ }^{20}$ and atopic symptoms, smoking habits and work history. Some of the questionnaire items were taken from the ECRHS.

\section{Spirometry}

Spirometry was carried out by experienced technicians according to European Respiratory Society standards using a pneumotachograph with specific software (Pneumotachograph and 4.66 software; Jaeger, Würzburg, Germany). ${ }^{21}$ Age- and heightadjusted spirometric reference values of the European Community for Steel and Coal were used. ${ }^{21}$ Non-specific bronchial hyper-responsiveness was assessed by methacholine bromide challenge. Methacholine bromide was administered during a controlled inspiratory capacity breathing Dosimeter technique using the Aerosol Provocation System with a Medic-Aid nebuliser (Jaeger), starting with diluent and followed by doubling of doses of methacholine bromide from $0.12 \mathrm{mg}$ to a maximum dose of $1.87 \mathrm{mg}(7.8 \mu \mathrm{mol})$, the cut-off point for a normal response. $^{21}$ The test was stopped when a fall of $20 \%$ in $\mathrm{FEV}_{1}$ (forced expiratory volume in $1 \mathrm{~s}$ ) was observed (PD20) or the maximum cumulative dose was reached. If necessary, bronchoconstriction was treated with inhalation of salbutamol. ${ }^{22}$

We defined airway obstruction as a $\mathrm{FEV}_{1}<80 \%$ of predicted and a $\mathrm{FEV}_{1}$ to $\mathrm{FVC}$ (forced vital capacity) ratio of $\leq 70 \%$.

\section{Serology and eosinophil count}

Blood samples were cooled and transported to a nearby hospital laboratory for analyses. The concentration of eosinophils was measured with a Cell-Dyn Sapphire analyser (Abbott Laboratories, Abbott Park, Illinois, USA). An increased concentration of eosinophils was defined as $\geq 0.4 \times 10^{9} / 1$. We used enzyme immunoassays to assess total serum IgE and specific IgE reactions to a panel of common environmental allergens (house dust mites, cat, dog, and grass and birch pollen). Total and specific IgE to common aeroallergens were analysed in our laboratory based on adjusted previously published methods. ${ }^{23}$ A total IgE of $>100 \mathrm{kU} / 1$ and/or at least one positive reaction to common allergens was defined as atopy.

\section{Epidemiological and statistical analysis}

All statistical analyses were performed using SAS v 9.1. Data for 144 male workers aged between 30 and 65 years were used to 
compare the prevalence of respiratory symptoms among workers with the prevalence in the general population sample. Data for 138 Caucasian male workers aged between 30 and 65 years were used to compare spirometric test results among workers with those of the general population sample. Multiple linear regression analysis was used to compare personal characteristics and the spirometric test results of workers with those of the general population sample, adjusting for age and height. Spirometric test results were also investigated by multiple linear regression analysis (PROC REG), adjusting for age, height and smoking habits (categorical variable: never, former or current smoker). The accuracy of regression models was examined by using Cook's D influence statistic, residual plots and partial regression residual plots and when indicated, sensitivity analyses were performed with log-transformed lung function variables.

Workers were assigned to different exposure groups based on their current job in their self-reported work history. Data for 140 Caucasian male workers (all ages) were used to compare respiratory symptoms between different exposure groups within the study population using minimally irritant exposed workers as an internal reference group. Data for 139 Caucasian male workers (all ages) were used to compare spirometric test results between different exposure groups within the study population using minimally irritant exposed workers as an internal reference group. Spirometric test results in different exposure groups were also investigated by multiple linear regression analysis (PROC REG), adjusting for age, height and smoking habits. For all questionnaire items, we calculated prevalence ratios (PR) and $95 \% \mathrm{CIs}$ by $\log$ binomial regression analysis. ${ }^{24}$ A starting value of -4 for the intercept was used to prevent convergence problems. ${ }^{25}$ PRs were adjusted for age and smoking habits. Two-sided $p$ values of 0.05 or less were considered to represent associations unlikely to be due to chance.

\section{RESULTS}

\section{Participants}

The personal characteristics of the aluminium cast-house workers are given In table 1 and include the numbers of workers in the exposure groups, the median years of employment, spirometry and blood test results.

\section{Exposure assessment}

A total of 88 personal inhalable dust samples were available (GM $0.76 \mathrm{mg} / \mathrm{m}^{3}$; GSD $2.35 \mathrm{mg} / \mathrm{m}^{3}$; range $\left.0.05-5.79 \mathrm{mg} / \mathrm{m}^{3}\right)$. All samples were below the occupational exposure limit (OEL) for inhalable dust $\left(10 \mathrm{mg} / \mathrm{m}^{3}\right)$, with an overall probability of exceedance of the OEL of $0.1 \%$.

Metal analyses in personal and sedimentation dust revealed that the main metals in the dust were aluminium (47-90\%), iron (15-18\%), magnesium (2-14\%) and sodium (1-15\%). In addition, small amounts $(0.1-3 \%)$ of other metals were found (borium, chromium, copper, manganese, selenium and titanium). No detectable levels of beryllium were found.

Measurement of the full-shift personal fluoride exposure of workers $(\mathrm{N}=6)$ showed detectable but relatively low fluoride exposure levels (range of total fluoride exposure 0.021$0.261 \mathrm{mg} / \mathrm{m}^{3}$ ), with HF accounting for $53-63 \%$ of the total fluoride exposure (gaseous and particulate). The full-shift fluoride area samples $(\mathrm{N}=6)$ were well below the Dutch $8 \mathrm{~h}$ OELs $\left(1.5 \mathrm{mg} / \mathrm{m}^{3}\right.$ for $\mathrm{HF}$ and $2.5 \mathrm{mg} / \mathrm{m}^{3}$ for inorganic fluorides), except for one sample taken high (approx $8 \mathrm{~m}$ above ground
Table 1 Characteristics of aluminium cast-house workers $(n=151)$

\begin{tabular}{|c|c|}
\hline \multicolumn{2}{|l|}{ Sex } \\
\hline Male (\%) & $150(99.3)$ \\
\hline Caucasian (\%) & 141 (93.4) \\
\hline \multicolumn{2}{|l|}{ Age, years } \\
\hline Median & 45 \\
\hline IQR & 13 \\
\hline \multicolumn{2}{|l|}{ Smoking status $(\%)$} \\
\hline Current smoker & $76(50.3)$ \\
\hline Former smoker & $42(27.8)$ \\
\hline Never smoked & $33(21.9)$ \\
\hline \multicolumn{2}{|l|}{ Exposure to irritants (\%) } \\
\hline High & $45(29.8)$ \\
\hline Moderate & $51(33.8)$ \\
\hline Low & $55(36.4)$ \\
\hline \multicolumn{2}{|l|}{ Duration of employment $(n=148)$} \\
\hline Median years of employment & 19 \\
\hline IQR & 16 \\
\hline \multicolumn{2}{|l|}{ Spirometry $(n=155)$} \\
\hline $\mathrm{FEV}_{1} \%$ pred $(\mathrm{SD})$ & $103.1(14.4)$ \\
\hline FVC \% pred (SD) & $108.7(13.8)$ \\
\hline PEF \% pred (SD) & $115.2(20.3)$ \\
\hline $\mathrm{FEV}_{1} / \mathrm{FVC} \%$ (SD) & $77.2(6.9)$ \\
\hline \multicolumn{2}{|l|}{ Methacholine bromide challenge $(n=149)$} \\
\hline BHR $(\%)$ & $17(11.4)$ \\
\hline \multicolumn{2}{|l|}{ Serology $(n=156)$} \\
\hline Atopy $(\%)$ & $50(32.1)$ \\
\hline Total lgE $>100 \mathrm{kU} / \mathrm{l}$ & $18(11.5)$ \\
\hline Sensitised to $\geq 1$ common allergen & $15(9.6)$ \\
\hline Total $\lg \mathrm{E}>100 \mathrm{kU} / \mathrm{l}$ and $\geq 1$ common allergen & $17(10.9)$ \\
\hline \multicolumn{2}{|l|}{ Blood test $(n=150)$} \\
\hline Eosinophils $\geq 0.4 \times 10^{9} /(\%)$ & $18(12.0)$ \\
\hline
\end{tabular}

level) in the cast-house area directly above one of the melting/ mixing furnaces. All short-term fluoride area samples $(\mathrm{N}=17)$ were below the detection limit. The low average fluoride concentrations were confirmed by the urine samples $(\mathrm{N}=55)$, with urine concentrations up to $1.81 \mathrm{mg}$ fluoride/g creatinine. Post-shift fluoride urine values were slightly elevated for most workers compared with the pre-shift values, but all values were well below the American Conference of Governmental Industrial Hygienists-Biological Exposure Indices or German Biologische Arbeitsplatztoleranzwerte values for urinary fluorides.

HF emissions, measured with the real-time TDL-based instrument, are shown in figure 1. Each time a transport ladle was emptied into a melting/mixing furnaces, high levels of HF could be measured in the smoke plume above the furnaces, which were much higher than the short-term exposure limit for HF of $1.5 \mathrm{ppm}$, and were occasionally as high as $60 \mathrm{ppm}$. Similar peak emissions occurred every few minutes within the casthouse area. The amount of smoke generated during this activity varied greatly, but the height of the HF peak did not vary much and seemed to be independent of (visible) smoke generation.

Real-time walk-through monitoring sessions showed no detectable levels of sulphur dioxide within the cast-house area. Chlorine concentrations were low during most walk-through monitoring sessions, but could rise to $8.8-11.8 \mathrm{mg} / \mathrm{m}^{3}$ (3-4 ppm) on several occasions when workers were taking test samples out of the induction oven (a daily activity taking only a few minutes). On one occasion a chlorine peak of $88.5 \mathrm{mg} / \mathrm{m}^{3}$ (30 ppm) was measured which appeared to be due 


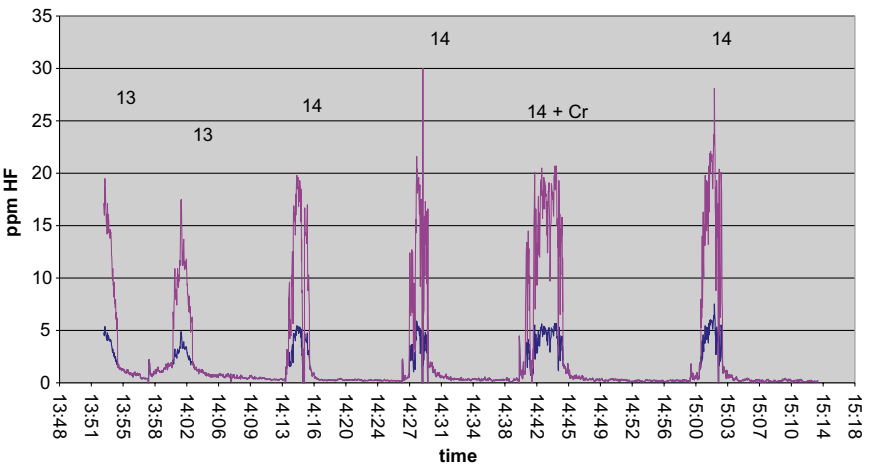

September 30th 2008 holding furnace 13 and 14

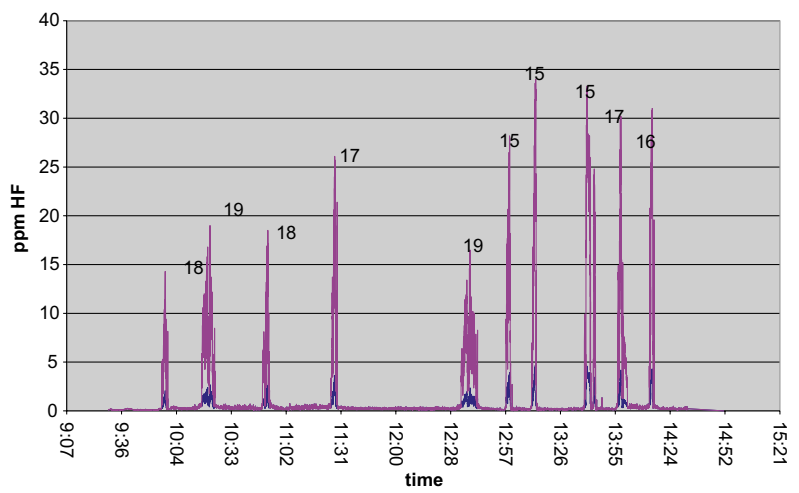

October 13th 2008 holding furnace $15-19$

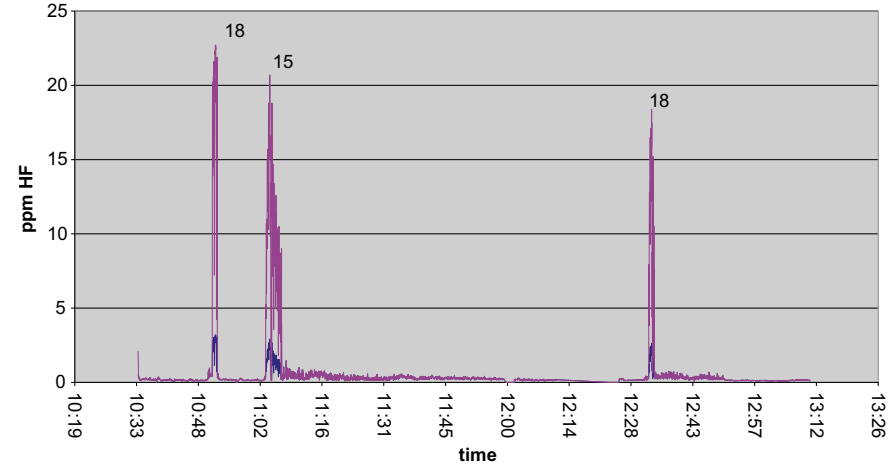

October 17th 2008 holding furnace 15 and 18

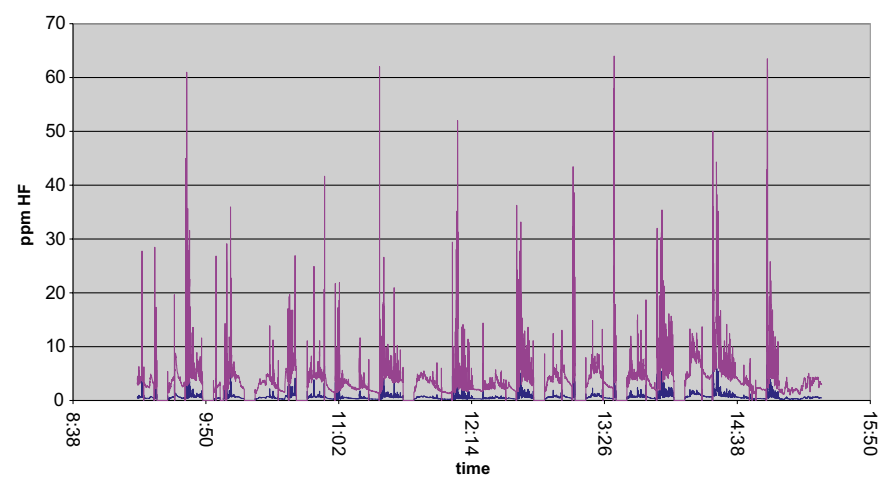

October 22nd 2008 TAC

Figure 1 Hydrogen fluoride measurements over time with peak exposures during furnace filling and sodium cleaner with $\mathrm{AlF}_{3}(\mathrm{TAC})$ (averaging time of the sampler $2 \mathrm{~s})$. HF, hydrogen fluoride.

to a leakage in one of the chlorine ducts; during the same sampling session workers said that similar leakages occurred on a regular base.

\section{Questionnaire and spirometry}

Compared with the Dutch ECRHS population, cast-house workers reported significantly more continuous and repeated trouble with breathing, exercise induced shortness of breath, wheezing, self-reported asthma attacks and physician diagnosed asthma attacks (table 2 ).

The spirometric test results of 138 Caucasian male aluminium cast-house workers showed significant differences in $\mathrm{FEV}_{1}$ and $\mathrm{FEV}_{1} / \mathrm{FVC}$ values (percentage of the predicted value) compared to a general Dutch population sample after adjusting for smoking habits (table 3).

Regression analysis showed that aluminium cast-house workers had significantly lower $\mathrm{FEV}_{1}$ values $(-195 \mathrm{ml})$ and FVC values $(-142 \mathrm{ml}$ ) compared to a general Dutch population sample after adjusting for age, height and smoking habits (table 4). Regression coefficients for age and height were comparable to those from reference regression equations from the European Respiratory Society. Current and former smokers generally had lower lung function compared with non-smokers. Cook's D influence statistic and residual plots indicated that FER assumptions underlying ordinary least squares regression were not completely met. Logarithmic transformation of the FER resulted in a somewhat better fit, but did not change associations, indicating the robustness of the model.

\section{Exposure-response relationship}

Workers in the high exposure group reported significantly more eye symptoms during their work (PR 5.5, 95\% CI 1.2 to 24.9) and workers in the moderate exposure group reported significantly more chest tightness symptoms when waking up (PR 3.0, $95 \%$ CI 1.1 to 8.2 ) compared to an internal reference group. Furthermore, there were no significant differences in selfreported respiratory symptoms among exposure groups. There were also no significant differences among exposure groups in bronchial hyper-responsiveness, atopy and eosinophils $\geq 0.4 \times 10^{9} / 1$. An unadjusted logistic regression analysis was used to explore associations between total years of employment at the plant and atopy $(\mathrm{OR}=1.0,95 \%$ CI 1.0 to 1.0$)$ and eosinophil levels $\geq 0.4$ (OR=1.0, 95\% CI 1.0 to 1.1$)$. No significant associations were observed.

The spirometric test results of 139 Caucasian male aluminium cast-house workers showed no significant differences (percentage of the predicted value) compared to a minimally exposed internal reference group after adjusting for smoking habits (data not shown). Regression analysis also showed no significant differences compared to a minimally exposed internal reference group after adjusting for age, height and smoking habits.

\section{Work-related airway symptoms}

Of 151 cast-house workers, 21 (13.9\%) reported an asthma attack (ever). Of these 21 workers, 10 (47.6\%) reported having had an asthma attack (ever) before they had started working at the plant, 8/21 (38.1\%) after they had started working at the plant and in $3 / 21(14.3 \%)$ it was not clear whether they had asthma attacks before or after they had started working at the plant.

Of 151 workers, 75 (49.7\%) reported having work-related upper and/or lower airway symptoms, 16 (21.3\%) of whom reported an asthma attack (ever) and 14 (18.7\%) of whom 
Table 2 Adjusted prevalence ratios with $95 \% \mathrm{Cl}$ of respiratory symptoms in cast-house workers and a general Dutch population sample of the European Community Respiratory Health Survey

\begin{tabular}{|c|c|c|c|}
\hline & \multicolumn{3}{|c|}{$\begin{array}{l}\text { Comparison with external reference } \\
\text { population } \dagger\end{array}$} \\
\hline & $\begin{array}{l}\text { Aluminium cast- } \\
\text { house workers } \\
n=144 \\
n(\%)\end{array}$ & $\begin{array}{l}\text { General } \\
\text { population } \\
\mathrm{n}=1000 \\
\%\end{array}$ & PR (95\% Cl) \\
\hline \multicolumn{4}{|l|}{ Trouble with breathing } \\
\hline Ever & $53(36.8)$ & 18.9 & $1.9(1.5 \text { to } 2.5)^{*}$ \\
\hline Continuously & $9(6.3)$ & 2.7 & $2.5(1.2 \text { to } 5.3)^{*}$ \\
\hline Repeatedly & $18(12.5)$ & 6.9 & $1.8(1.1 \text { to } 3.0)^{*}$ \\
\hline \multicolumn{4}{|l|}{ Cough symptoms } \\
\hline Daily cough & $22 / 55(40)$ & 14.7 & \\
\hline Daily cough with phlegm & $18 / 51(35.3)$ & 11.2 & \\
\hline \multicolumn{4}{|c|}{ Shortness of breath (SOB) and wheezing } \\
\hline Exercise induced $\mathrm{SOB}$ & $46(31.9)$ & 19.4 & $1.7(1.3 \text { to } 2.3)^{*}$ \\
\hline Awakened due to SOB & $11(7.6)$ & 6.1 & $1.4(0.7$ to 2.6$)$ \\
\hline Wheezing & $47(32.6)$ & 24.1 & $1.4(1.1 \text { to } 1.8)^{*}$ \\
\hline Wheezing with SOB & $37(25.7)$ & 14.6 & $1.8(1.3 \text { to } 2.5)^{*}$ \\
\hline Awakened due to chest tightness & $20(13.9)$ & 12.4 & $1.2(0.8$ to 1.8$)$ \\
\hline \multicolumn{4}{|l|}{ Asthma } \\
\hline Asthma attack (ever) & $20(13.9)$ & 5.2 & $2.8(1.7 \text { to } 4.6)^{*}$ \\
\hline Asthma attack, doctor diagnosed & $17(11.8)$ & 4.8 & $2.6(1.5 \text { to } 4.4)^{*}$ \\
\hline
\end{tabular}

${ }^{*} p<0.05$; adjusted for age and smoking habits (categorical variable: never, former or current smoker).

†Males only, aged between 30 and 65 .

$\mathrm{PR}$, prevalence ratio.

reported they had changed job because of their symptoms. Of these 14 cast-house workers who had changed job, 10 (71.4\%) reported an asthma attack (ever), 4 (40\%) of them after they had started working at the plant. In the group with work-related upper and/or lower airway symptoms, 64/69 workers (92.8\%) reported that their symptoms improved on non-working days.

An additional analysis of Caucasian males $(n=140)$ showed that cast-house workers who reported work-related upper and/ or lower airway symptoms, reported significantly more asthma attacks (ever) (PR 3.7, 95\% CI 1.3 to 10.6) after adjusting for age and smoking habits compared to those who did not report upper and/or lower work-related airway symptoms.

In an additional interview with the 14 cast-house workers who changed jobs, 13 (92.9\%) confirmed that they changed job as a result of their work-related upper and/or lower airway symptoms. One worker reported to have had work-related upper and/or lower airway symptoms and an asthma attack (ever) changed his job as a result of Ménière's syndrome. Five (38.5\%)
Table 3 Personal characteristics and spirometric test results of aluminium cast-house workers versus a general Dutch population sample of the European Community Respiratory Health Survey

\begin{tabular}{|c|c|c|}
\hline & $\begin{array}{l}\text { Cast-house workers } \dagger \\
n=138\end{array}$ & $\begin{array}{l}\text { General population } \dagger \\
\mathbf{n}=\mathbf{9 7 2}\end{array}$ \\
\hline Age (years), mean (SD) & $47(8.1)$ & $48(10.2)$ \\
\hline \multicolumn{3}{|l|}{ Smoking status (\%) } \\
\hline Current smoker & 48 & 42 \\
\hline Former smoker & 30 & 38 \\
\hline Never smoked & 22 & 20 \\
\hline $\mathrm{FEV}_{1} \%$ pred (SD) & $102.8(14.2)^{*}$ & $106.0(17.2)$ \\
\hline FVC \% pred (SD) & $108.6(13.5)$ & $109.2(14.4)$ \\
\hline PEF \% pred (SD) & $115.9(20.8)$ & $115.6(21.9)$ \\
\hline $\mathrm{FEV}_{1} / \mathrm{FVC} \%$ (SD) & $76.8(7.0)^{*}$ & $78.5(8.3)$ \\
\hline$\ddagger$ Airway obstruction & $6(4.3)$ & $51(5.2)$ \\
\hline
\end{tabular}

of these 13 workers reported an exposure incident, three of which were chlorine gas incidents. Nine (69.2\%) of the 13 workers had asthma and used asthma medications; eight of the nine were treated by a pulmonologist and one by a general physician. Seven of the nine stated that they had no asthma symptoms when they started working at the plant. Of the other four workers in the group of 13 , one had chronic obstructive pulmonary disease and three had no clear diagnosis.

\section{DISCUSSION}

Aluminium cast-house workers reported significantly more respiratory symptoms and showed significantly lower spirometric values compared to a sample of the Dutch ECRHS population.

The average daily mean exposure to inhalable dust, metals, HF, fluoride salts and sulphur dioxide was relatively low compared to reference values. However, high emission of fluoride occurred above the furnaces. The ventilation in the cast-house consisted of a natural ventilation system with ventilation grids automatically opening and closing in a controlled manner. When the ventilation grids were open, the outside wind influenced the airflow patterns within the cast house, disturbing the upward airflow patterns above the ovens. This resulted in pot emissions with high concentrations of fluorides spreading into the workplace. Measurements showed that peak exposures to chlorine gas occurred as a result of production process disturbances.

Table 4 Multiple linear regression analysis of pulmonary function variables on age, height and smoking habit in a population of cast-house workersł

\begin{tabular}{|c|c|c|c|c|c|c|c|c|}
\hline \multirow[b]{2}{*}{ Determinant } & \multicolumn{2}{|l|}{$\mathrm{FEV}_{1}(\mathrm{ml})$} & \multicolumn{2}{|l|}{ FVC (ml) } & \multicolumn{2}{|l|}{ PEF (ml/s) } & \multicolumn{2}{|l|}{ FEV $_{1} /$ FVC \% } \\
\hline & $\beta$ Coefficient & $95 \% \mathrm{CI}$ & $\bar{\beta}$ Coefficient & $95 \% \mathrm{CI}$ & $\bar{\beta}$ Coefficient & $95 \% \mathrm{CI}$ & $\beta$ Coefficient & $95 \% \mathrm{CI}$ \\
\hline Intercept & -3329 & -4306 to -2352 & -6223 & -7272 to -5174 & -2849 & -5946 to 248 & 111 & 98 to 124 \\
\hline Age & $-38^{*}$ & -41 to -34 & $-33^{*}$ & -37 to -27 & $-64^{*}$ & -76 to -52 & $-0.26 *$ & -0.31 to -0.21 \\
\hline Height & $5204^{*}$ & 4690 to 5717 & $7290^{*}$ & 6739 to 7842 & $9263^{*}$ & 7635 to 10891 & $-11^{*}$ & -18 to -4 \\
\hline \multicolumn{9}{|l|}{ Smoking status (\%)§ } \\
\hline Current smoker & $-236^{*}$ & -329 to -143 & $-124^{*}$ & -224 to -24 & $-424^{*}$ & -720 to -129 & $-2.66^{*}$ & -3.87 to -1.44 \\
\hline Former smoker & -31 & -129 to 67 & -42 & -147 to 62 & 209 & -100 to 518 & 0.12 & -1.15 to 1.39 \\
\hline Cast house $\Phi$ workers & $-195^{*}$ & -306 to -85 & $-142^{*}$ & -260 to -24 & -155 & -505 to 194 & $-1.26 \dagger$ & -2.70 to 0.18 \\
\hline Adjusted $\mathrm{R}^{2}(\%)$ & 51 & & 54 & & 24 & & 11 & \\
\hline
\end{tabular}

${ }^{*} \mathrm{p}<0.05 ;+p<0.10$.

$\neq n=138$, Caucasian males only, aged between 30 and 65 .

$\S$ Never smoked as reference group.

TGeneral population as reference group ( $n=972$ ), Caucasian males only, aged between 30 and 65 .

$\mathrm{FEV}_{1}$, forced expiratory volume in $1 \mathrm{~s}$; FEV $/$ FVC, forced expiration ratio; FVC, forced vital capacity; PEF, peak expiratory flow. 
Compared to a minimally irritant exposed internal reference group, cast-house workers in the group with the highest exposure to irritants reported significantly more eye symptoms during their work and workers in the moderate exposed group reported significantly more chest tightness symptoms when waking up. No differences in spirometric values were found between exposure groups.

Cast-house workers who reported work-related airway symptoms reported significantly more asthma attacks compared to workers without work-related airway symptoms. The majority of cast-house workers who reported job change due to their symptoms reported asthma.

The average daily mean exposure to inhalable dust, metals, HF, fluoride salts and sulphur dioxide was relatively low compared to reference values. However, peak emissions of HF and fluoride salts occurred in the cast-house area when aluminium was poured from transport ladles into the furnaces. Normal airflow patterns in the workplace were disturbed on a regular base and, as a result, emissions from transport ladles with high concentrations of HF and fluoride salts spread into the workplace. So, peak exposures to HF and fluoride salts are very likely but were difficult to measure due to their unpredictable nature.

Measurements showed that peak exposures to chlorine gas can occur as a result of specific production process disturbances. This was confirmed by workers during walk-through surveys and during medical interviews with workers who changed job due to symptoms. Thus, intermittent exposures to irritants are relevant to cast-house workers. In particular, exposures to fluorides were not restricted to certain tasks or jobs but depended on weather conditions and airflow patterns in the workplace and as a result were quite homogeneous for all cast-house workers within the cast-house area.

In their study among 30 cast-house workers and 17 controls, Godderis et al found no significant difference in any of the respiratory questionnaire categories or in spirometry results between cast-house personnel and referents and concluded that there was no indication for respiratory health problems in cast-house personnel compared to the referent population. ${ }^{15}$

In our study we also found no significant differences in any of the respiratory questionnaire categories or in the spirometry results between cast-house personnel and internal referents. In addition, spirometry results were not associated with duration of employment as a proxy for cumulative exposure to irritants (data not shown).

However, cast-house workers do have respiratory health problems compared to a general population sample and these problems are likely to be underestimated.

Godderis et al concluded that exposure levels in cast houses seemed to be acceptable but that peak exposure to fumes could not be excluded. Our study shows that exposures measured in the workplace are on average within acceptable limits but that peak exposures to respiratory irritants occurred on a regular basis as a result of disturbances in the airflow pattern and more intermittent exposures to chlorine gas.

Our study suggests that these peak exposures to irritants may explain the respiratory health effects in exposed cast-house workers in comparison to the general population.

In an internal comparison of groups exposed to irritants, the highest exposed group reported significantly more eye symptoms during their work and workers in the moderate exposed group reported significantly more chest tightness symptoms when waking up. These symptoms may be a result of irritation by fluorides and/or chlorine. ${ }^{26} 27$ The homogeneous character of exposures among cast-house workers may explain why we did not find more differences in respiratory symptoms among exposure groups.

Furthermore, cast-house workers who reported work-related airway symptoms reported significantly more asthma attacks compared to workers without work-related airway symptoms and most of those who reported job change due to their symptoms also reported asthma.

Most workers with physician diagnosed asthma reported they had no asthma symptoms when they started working at the plant. These findings may be an indication that exposures in cast-house workers either caused or aggravated symptoms of asthma. Indeed, exposure to irritants can aggravate or probably cause asthma. ${ }^{28}$ Kipen et al reported cases of non-sensitisation adult-onset asthma in settings of exposure to noticeable but distinctly 'tolerable' levels of inhalation irritants and Taiwo et al demonstrated a significant relationship between mean gaseous fluoride exposure and the incidence rate of asthma but were unable to show any significant association between short-term HF exposure and asthma incidence in their study population. ${ }^{10} 29$ Furthermore, Simonsson et al showed acute and long-term airway hyper-responsiveness in a case series of aluminium-salt exposed workers with nocturnal asthma. ${ }^{30}$

Whether cast-house workers with asthma had 'potroom asthma' as described in aluminium potroom workers ${ }^{1}$ cannot be concluded from this study because cases were not further evaluated. But even then, although the bronchial responsiveness in aluminium potroom workers reporting work-related asthmatic symptoms appeared to be related to plasma levels of fluoride, the causative agent of potroom asthma has still not been elucidated. ${ }^{2}$ However, Burge et al raised the possibility, in a case report, that potroom asthma is the result of a response to aluminium fluoride. ${ }^{31}$

The study population was small, and this limited statistical power in internal comparisons, especially after adjusting for confounding variables in multiple regression modelling.

Information was collected in a standard manner and exposure was assigned blind to the questionnaire and test results. As a result, misclassification will likely to be non-differential and exposure-response relationships might have been underestimated.

Cast-house workers reported significantly more respiratory symptoms and showed significantly lower spirometric values compared to the Dutch ECRHS population. However, overestimation of symptoms in workers cannot be excluded, and recall bias may have affected comparisons with the general population. Nevertheless, the workers also showed significantly lower spirometric values which are a more objective outcome. Reversibility in $\mathrm{FEV}_{1}$ was not measured, so it was not possible to evaluate the nature of the spirometric changes.

The general population data were obtained using the same procedure and device, with the same age and distribution, but were not restricted to a working subpopulation. The general population sample also included non-active workers who were not fit enough to be active in the workforce; therefore, the differences in respiratory status between exposed workers and the general population are likely to be underestimated.

The healthy worker effect is a potential source of bias in crosssectional studies when restricted to actively employed workers Leaving employment or job transfer to lower exposure as a result of disease may have led to underestimation of the effects of exposure. $^{32} 33$

Job transfer may have led to an underestimation of exposureresponse relationships in this study, because 14 workers reported they had changed job during their employment at this plant as a result of work-related airway symptoms. The company 
initiated several control measures after the study. Filling pipes in the ovens were shortened to avoid the situation whereby liquid metal in the oven closes off the filling pipe thus increasing the emission of heat and fumes at the oven inlet. In addition, local ventilation is being installed above oven inlets. Both measures aim to reduce the emission of fumes and gasses to the cast-house area, although the effectiveness has not been measured at this time.

In conclusion, this epidemiological study suggests cast-house workers in the aluminium industry are exposed to respiratory risk. Although an exposure-response relationship could not be demonstrated, this study supports preventive measures in the working environment of cast-house workers with a focus on (peak) exposures to irritants. Exposure should be minimised and health surveillance should be offered to exposed workers.

Acknowledgements The authors thank Professor Dr Johny Kongerud (Rikshospitalet, Oslo University, Norway) who reviewed the draft manuscript and provided helpful suggestions for improvements.

Funding This study was supported. A contract guaranteed independence of the research group according to criteria set by the Dutch Royal Academy of Sciences (KNAW) in close collaboration with the occupational health service.

Competing interests None.

Provenance and peer review Not commissioned; externally peer reviewed.

\section{REFERENCES}

1. Kongerud J, Boe J, Søyseth V, et al. Aluminium potroom asthma: the Norwegian experience. Eur Respir J 1994;7:165-72.

2. Søyseth V, Kongerud J, Ekstrand J, et al. Relation between exposure to fluoride and bronchial responsiveness in aluminium potroom workers with work-related asthma-like symptoms. Thorax 1994;49:984-9.

3. Søyseth V, Kongerud J, Kjuus $\mathrm{H}$, et al. Bronchial responsiveness and decline in FEV1 in aluminium potroom workers. Eur Respir J 1994:7:888-94.

4. Desjardins A, Bergeron JP, Ghezzo H, et al. Aluminium potroom asthma confirmed by monitoring of forced expiratory volume in one second. Am J Respir Crit Care Med 1994;150:1714-17.

5. Sorgdrager B, de Looff AJ, de Monchy JG, et al. Occurrence of occupational asthma in aluminum potroom workers in relation to preventive measures. Int Arch Occup Environ Health 1998;71:53-9.

6. Chan-Yeung M, Wong R, MacLean L, et al. Epidemiologic health study of workers in an aluminum smelter in British Columbia. Effects on the respiratory system. Am Rev Respir Dis 1983;127:465-9.

7. Abramson MJ, Wlodarczyk JH, Saunders NA, et al. Does aluminum smelting cause lung disease? Am Rev Respir Dis 1989;139:1042-57.

8. O'Donnell TV, Welford B, Coleman ED. Potroom asthma: New Zealand experience and follow-up [erratum appeared in Am J Ind Med 1989:16:337]. Am J Ind Med 1989;15:43-9.

9. Kongerud J. Respiratory disorders in aluminium potroom workers. Med Lav 1992:83:414-17.

10. Taiwo $\mathbf{0 A}$, Sircar KD, Slade MD, et al. Incidence of asthma among aluminum workers. J Occup Environ Med 2006:48:275-82.
11. Kongerud J, Soyseth V, Burge S. Serial measurements of peak expiratory flow and responsiveness to methacholine in the diagnosis of aluminium potroom asthma. Thorax 1992:47:292-7.

12. Fritschi $\mathbf{L}, \operatorname{Sim} M R$, Forbes $A$, et al. Respiratory symptoms and lung-function changes with exposure to five substances in aluminium smelters. Int Arch Occup Environ Health 2003;76:103-10.

13. Fritschi $\mathbf{L}$, Beach J, Sim M, et al. Respiratory symptoms and lung function in two prebake aluminum smelters. Am J Ind Med 1999;35:491-8.

14. Field G. Respiratory problems in the Australian Aluminium industry. $J$ Occup Health Safety-Aust NZ 1989;5:415-19.

15. Godderis L, Vanderheyden W, Van Geel J, et al. Exposure and inhalation risk assessment in an aluminium cast-house. J Environ Monit 2005: 7:1359-63.

16. Doko Jelinic J, Mustajbegovic J, Zuskin E, et al. Managing occupational safety and health in aluminum production: case study of aluminum production factory, Mostar Bosnia and Herzegovina. Croat Med J 2005;46:838-47.

17. Rijcken B, Kerkhof M, de Graaf A, et al. Europees luchtweg onderzoek Nederland Groningen: Stichting drukkerii Regenboog, 1996.

18. HSE. MDHS 35/2. Hydrogen Fluoride and Fluorides in Air: MDHS 35/2, 1998:1-16 Health and Safety Executive, Sudbury, UK. http://www.hse.gov.uk/pubns/mdhs/pdfs/ mdhs35-2.pdf.

19. NIOSH method 8308. Fluoride in urine. NIOSH Manual of Analytical Methods (NMAM). 4th edn, 1994. National Institute for Occupational Safety and Health (NIOSH), Cincinnati, USA. http://www.cdc.gov/niosh/docs/2003-154/pdfs/8308.pdf.

20. Heederik D, Heldal KK, Artenie RC, et al. Working Group report 2: questionnaires for work-related symptoms after organic dust exposure. Am J Ind Med 2004:46:414-15.

21. Quanjer PH, Tammeling GJ, Cotes JE, et al. Lung volumes and forced ventilatory flows. Report Working Party Standardization of Lung Function Tests, European Community for Steel and Coal. Official Statement of the European Respiratory Society. Eur Respir J Suppl 1993;16:5-40.

22. Sterk PJ, Fabbri LM, Quanjer PH, et al. Airway responsiveness. Standardized challenge testing with pharmacological, physical and sensitizing stimuli in adults. Report working party standardization of lung function tests, european community for steel and coal. Official statement of the european respiratory society. Eur Respir $J$ Supp/ 1993:16:53-83.

23. Doekes G, Douwes J, Wouters I, et al. Enzyme immunoassays for total and allergen specific IgE in population studies. Occup Environ Med 1996;53:63-70.

24. Thompson ML, Myers JE, Kriebel D. Prevalence odds ratio or prevalence ratio in the analysis of cross sectional data: what is to be done? Occup Environ Med 1998:55:272-7.

25. Deddens JA, Petersen MR. Approaches for estimating prevalence ratios. Occup Environ Med 2008;65:501-6.

26. Lund K, Ekstrand J, Boe J et al. Exposure to hydrogen fluoride: an experimental study in humans of concentrations of fluoride in plasma, symptoms, and lung function. Occup Environ Med 1997;54:32-7.

27. The International Programme on Chemical Safety (IPCS). http://www.inchem.org/ documents/pims/chemical/pim947.htm.

28. Tarlo SM, Balmes J, Balkissoon R, et al. Diagnosis and management of work-related asthma: American College Of Chest Physicians Consensus Statement. Chest 2008;134(3 Suppl):1S-41

29. Kipen HM, Blume R, Hutt D. Asthma experience in an occupational and environmental medicine clinic. Low-dose reactive airways dysfunction syndrome. J Occup Med 1994;36:1133-7.

30. Simonsson BG, Sjöberg A, Rolf $\mathrm{C}$, et al. Acute and long-term airway hyperreactivity in aluminium-salt exposed workers with nocturnal asthma. Eur $J$ Respir Dis 1985;66:105-18.

31. Burge PS, Scott JA, McCoach J. Occupational asthma caused by aluminum. Allergy 2000;55:779-80

32. Eisen EA. Healthy worker effect in morbidity studies. Med Lav 1995:86:125-38

33. Eisen EA, Wegman DH, Louis TA, et al. Healthy worker effect in a longitudinal study of one-second forced expiratory volume (FEV1) and chronic exposure to granite dust. Int J Epidemiol 1995:24:1154-61. 